\title{
Attitudes of Students Studying In Health Related Departments towards the Elderly
}

\section{Sağlıkla İlgili Bölümlerde Okuyan Öğrencilerin Yaşlılara Yönelik Tutumları}

\author{
Sercan Özbek YAZICI ${ }^{1}$ \\ Mehmet Akif Ersoy Üniversitesi \\ Işıl KALAYCI ${ }^{2}$ \\ Süleyman Demirel Üniversitesi \\ Esin KAYA ${ }^{3}$ \\ Mehmet Akif Ersoy Üniversitesi \\ Ayşe TEKİN ${ }^{4}$ \\ Mehmet Akif Ersoy Üniversitesi
}

\begin{abstract}
Negative attitudes towards the elderly may cause decreases in quality health service provided to the elderly. In the study, the aim was to determine attitudes of students studying in health related departments towards the elderly and relationships between the attitudes and various variables were analyzed.

In a descriptive study, the sample included nursing, physiotherapy, and elderly care students. Kogan's attitude towards old people scale (KAOP) was used to measure attitudes towards the elderly and Stanley Coopersmith Self Esteem Inventory (SEI) was used to assess the level of students' self-esteem.

The KOAP mean attitude score of the students was $125.6 \pm 14.38$ and the students had slightly positive attitudes towards the elderly. Students who were at the age of 20 or over and who were living in the city showed more positive attitudes. The students of the Elderly Care Department had the lowest mean score and there was a significant difference between mean KAOP scores of students at Nursing and Elderly Care Department. Also, weak positive correlation was found between the KAOP and SEI mean scores of students.

The results implies that the students are required to enhance their positive attitudes towards the elderly. Therefore, students should be provided a training program that improves the positive attitudes.
\end{abstract}

Key Words: Attitude, Education, Elderly, Student

\footnotetext{
${ }^{1}$ Yrd.Doç.Dr., Mehmet Akif Ersoy Üniversitesi, Sağlık Yüksekokulu, Beslenme ve Diyetetik Bölümü, E-mail: sozbek@mehmetakif.edu.tr

2 Öğr.Gör.Dr., Süleyman Demirel Üniversitesi, Sağlık Bilimleri Fakültesi, Hemşirelik Bölümü,

E-mail: isilkalayci@sdu.edu.tr

${ }^{3}$ Öğr.Gör., Mehmet Akif Ersoy Üniversitesi, Sağlık Yüksekokulu, Hemşirelik Bölümü,

E-mail: ekaya@mehmetakif.edu.tr

${ }^{4}$ Öğr.Gör., Mehmet Akif Ersoy Üniversitesi, Sağlık Yüksekokulu, Hemşirelik Bölümü,

E-mail: ayşetekin@mehmetakif.edu.tr
} 


\section{Özet}

Yaşlılara yönelik negatif tutumlar sağlık hizmetinin kalitesinde azalmaya neden olabilir. Bu çalışmada sağlıkla ilgili bölümlerde okuyan öğrencilerin yaşılara yönelik tutumlarının ve bu tutumların çeşitli değişkenlerle ilişkisinin belirlenmesi amaçlanmışır.

Tanımlayıcı tipteki bu çalışmada, örneklem hemşirelik, fizyoterapi ve yaşlı bakım bölümü öğrencilerinden oluşmaktadır. Öğrencilerin yaşlılara yönelik tutumlarını ölçmek için Kogan'nın Yaşıılara Yönelik Tutum Ölçeği (KAOP) kullanılırken, öğrencilerin benlik saygıları Coopersmith Benlik Saygısı Ölçeği (SEI) ile değerlendirildi.

Çalışmada, öğrencilerin KOAP toplam puan ortalaması $125.6 \pm 14.38^{\prime}$ dir ve yaşlılara yönelik zayıf bir pozitif tutuma sahip oldukları bulundu. 20 yaş ve üzeri olan ve şehirde yaşayan öğrenciler daha pozitif bir tutum gösterdi. Yaşı bakım bölümünde okuyan öğrenciler en düşük puan ortalamasına sahipti ve hemşirelik öğrencileri ile aralarında anlamlı bir fark vardı. Aynı zamanda, KOAP ve SEI puan ortalamaları arasında zayıf pozitif bir ilişki bulundu.

Elde edilen sonuçlar yaşılıra yönelik öğrencilerin pozitif tutumlarının artırılması gerektiğini göstermektedir. Bu amaçla öğrencilere tutumları geliştiren eğitim programları sağlanması gerekmektedir.

Anahtar Kelimeler: Tutum, Eğitim, Yaşlı, Öğrenci

\section{Introduction}

In Turkey, the elderly population is increasing at a higher speed than that of other age groups as is the case all over the world. In 2013, while the growth rate of total population was $13.7 \%$, growth rate of elderly population was almost triple with $36.2 \%$. The proportion of those aged 65 years or over was $7.7 \%$ and it is expected that this proportion will rise to $10.2 \%$ in 2023 (TUIK, 2013). This increase in the elderly population has brought about new insights and goals in issues related to the elderly in all areas of life.

Aging is a biological process affecting the whole organism and causing some physiological and anatomical changes in individuals. Because of the changes, the rate of chronic diseases and tendency to illnesses is increased and old people are more frequent users of hospitals (Leung, 2011). This situation reveals the need for continuous improvement of quality of life and care as well as providing appropriate treatment for the elderly. Thus, educational standards should be raised to prepare health professionals who can determine risks and health problems peculiar to aging. For this purpose, The Elderly Care Department has been established in universities, geriatric and gerontology courses have begun to be more important in health related departments and geriatric/gerontology courses have been organized for working health professionals in recent years in Turkey. These developments indicate that awareness about aging and the elderly is raised.

However, it is still insufficient to meet the need of trained professionals in the field of geriatrics and gerontology.

Health care professionals have an important role in the determination of the quality of health care (Yen et al., 2009). Negative attitudes towards the elderly and aging may cause decreases in efficiency and quality health service provided to the elderly (Chung et al., 2003). For this reason, attitudes of health care professionals and students should be identified to enhance the quality of 
health care for old people and to develop new educational strategies that promote positive attitudes toward the elderly and knowledge on aging.

During the past 50 years, there has been increasing interest on identification of attitudes of health care professionals and students towards the elderly. But the results from studies on attitudes are controversial. Doherty et al. (2011) have reported that nurses and students have positive attitudes towards old people. Conversely, negative attitudes were noted by Kearney et al., (2000). It is known that attitudes are affected by personal and environmental factors such as past life of the individual, education level and cultural values (İnceoğlu, 2010). Thus, the studies have focused on various variables such as personal characteristics, education and experience with the elderly to identify predictors of positive attitudes. Some researchers have reported that positive attitudes were related to age, gender, work experience, and living experience with the elderly (Leung et al., 2011; Usta Yıldırım et al., 2012). However, the same correlation wasn't suggested in other studies evaluating attitudes towards the elderly (Kearney et al., 2000; Lee, 2009). As is known, lack of knowledge about a particular population may result in negative attitudes. In the same way, previous studies have indicated that education level and knowledge on aging and the elderly is a significant factor influencing attitudes toward the elderly (Soderhamn et al., 2001; Hweidi Al-Obeisat, 2006; Lambrinou et al., 2009; Bleijenberg et al., 2012).

Another factor that may affect health care professionals' attitudes towards the elderly is their self-esteem. Self-esteem expresses an attitude of approval or disapproval towards oneself (Coopersmith 1986). Level of selfesteem affects all aspects of a person's life such as personal satisfaction, social relationships, academic achievement, and behaviors (Goodson et al., 2006). There's a strong job satisfaction/self-esteem relationship and people with high self-esteem tend to have positive attitudes about themselves and others (Barnoy et al., 2008). High self-esteem is an essential for health care professionals to have a therapeutic relationship with a patient and to provide quality care (Hamoud et al., 2011; Dimitriadou et al., 2014). Therefore, it can be expected that students with high self-esteem may have more positive attitudes toward the elderly.

The changes in feeling, experience and knowledge may have an effect on the individual's attitudes. It means that education can change attitudes (İnceoğlu, 2010). Likewise, self-esteem contributes to the formation of attitudes and behavior (Dimitriadou et al., 2014) and education plays an important role in the development of professional image and self-esteem (Öhlen and Segesten, 1998).

The aim of this study was to determine attitudes towards the elderly of the students trained in the Department of Nursing, Elderly Care, and Physical Therapy and Rehabilitation. In addition, relationships between the attitudes and various variables such as personal characteristics and students' self-esteem were analyzed. 


\section{Methods}

A descriptive correlation design was used to determine students' attitudes towards the elderly. The research was conducted at The Health Science Faculty (Nursing and Physical Therapy and Rehabilitation Departments), and Health Services Vocational School (Elderly Care Department) of XXXXX University, in the 2013-2014 academic year spring semester after obtaining permission from the relevant authorities of the University and students.

In the research, sampling was not done and it was aimed to reach all students $(n=867)$ who attended the departments. Two hundred sixty (260) of the students failed to participate because of such reasons as illness, absenteeism, registration on hold and unwillingness. 79 questionnaires were excluded from the analysis due to missing data. Therefore, the research was conducted with the remaining 310 Nursing, 172 Physiotherapy and 46 Elderly Care students for the total of 528 students. All the students were informed about the study and verbal consent of the students were obtained.

\section{Instruments}

Three forms were utilized as data collection tools: (1) "Personal Information Form" aimed at the determination of students' personal and family characteristics and some variables were categorized by two groups of age (younger vs. older than 20 years old), parents' education level, and income; (2) "Coopersmith Self Esteem Inventory" (SEI) aimed at determining the level of self-esteem; (3) "The Kogan's attitude towards old people scale" (KAOP) aimed at determining students' attitudes towards the elderly.

The Coopersmith Self Esteem Inventory (SEI) developed by Stanley Smith (1986) is a 25-item self-rating instrument with a 2-point rating scale (Coopersmith 1986). It was adapted to Turkish by Turan and Tufan (1987). The scores can range from 0 to 100 . Self-esteem does not have a certain limit. As it was reported, the scores obtained below the mean indicate low self-esteem, and those above indicate high self-esteem (Turan and Tufan, 1987).

In the study, attitudes of students towards the elderly were measured using Kogan's Scale (Kogan, 1961). The Scale was translated into Turkish, and its validity and reliability were studied by Erdemir et al. (2011). The necessary permission was obtained from the authors. The scale is a self-administered questionnaire and assesses attitudes towards the elderly with respect to norms and individual differences, stereotypes and misconceptions. The KAOP was developed by Nathan Kogan in 1961. Kogan's scale is the most commonly used instrument in the literature (Baker, 2005; Liu, 2012). The KAOP consists of 34 items regarding old people. The scale contains one set of 17 items expressing negative statements (KAOP-) and a second set of 17 items expressing positive statements $\left(\mathrm{KAOP}^{+}\right)$about old people. For the present research, the negative and positive items were placed in random order on the questionnaire. The scale is designed as a summed Likert attitude scale on six-point response categories that ranges from 1 (strongly disagree) to 6 (strongly agree). These categories were scored 1, 2, 3, 5 and 6, respectively, with a score of 4 assigned in the rare case of failure to respond to an item. To obtain a positive item score, the 
summing of the positive items is calculated separately from the negative items. A higher score on the positive scale indicates favorable attitudes. The negative statements are reversed to obtain the total score and lower scores indicate unfavorable attitudes. The possible total score was between 34 and 204. Higher total scores indicated a more positive attitude towards the elderly. A score of 102 is considered a neutral attitude (Kearney et al., 2000). The Cronbach's alpha was found to be 0.84 for the Turkish version.

\section{Analysis of The Data}

The data were analyzed using SPSS. Students' attitudes were identified using descriptive statistics. The effects of students' characteristics on their attitudes towards the elderly were examined by using the $t$ test and ANOVA (Tukey test in Post Hoc evaluation). Furthermore, the Pearson's correlation coefficient was used to test the relationship between students' self-esteem levels and attitudes towards the elderly. A difference was deemed statistically significant for $\mathrm{p}$-values less than 0.05 .

\section{Results}

Five hundred and twenty-eight participants (60.9\%) out of 867 fully completed the questionnaire. Of the all participants, $58.71 \%$ were nursing students, $32.57 \%$ were physiotherapy students and $8.72 \%$ were elderly care student. Students' age ranged from 18 to 32 years with mean age of $22.05 \pm 1.91$ years old. The majority of the participants were female $(69.1 \%)$, $89 \%$ had a nuclear family type, and $60.7 \%$ were from families that lived in the city. Also, we found that $36.6 \%$ of the students' mothers and $44.7 \%$ of their fathers' education level were high school and/or over and $40.5 \%$ had an income that was equal to expenditure. Personal and family characteristics of the students are presented in Table 1.

\begin{tabular}{|c|c|c|c|}
\hline $\begin{array}{c}\text { Personal } \\
\text { characteristics }\end{array}$ & N (\%) & $\begin{array}{c}\text { Self-esteem } \\
\text { scores } \\
\text { Mean- SD }\end{array}$ & $\begin{array}{c}\text { Attitude } \\
\text { (KOAP total } \\
\text { scores)Mean- SD }\end{array}$ \\
\hline $\begin{array}{c}\text { Age } \leq 20 \\
>20 \\
p\end{array}$ & $\begin{array}{cc}239 & (45.3) \\
289 & (54.7)\end{array}$ & $\begin{array}{r}73.6 \pm 14.28 \\
73.5 \pm 13.52 \\
0.970\end{array}$ & $\begin{array}{r}124.4 \pm 12.57 \\
127.02 \pm 16.21 \\
0.037 *\end{array}$ \\
\hline $\begin{array}{c}\text { Gender Female } \\
\text { Males } \\
p\end{array}$ & $\begin{array}{l}365(69.1) \\
163(30.9)\end{array}$ & $\begin{array}{r}74.3 \pm 13.30 \\
71.9 \pm 14.92 \\
0.060 \\
\end{array}$ & $\begin{array}{r}126.1 \pm 15.01 \\
124.2 \pm 12.80 \\
0.129 \\
\end{array}$ \\
\hline $\begin{array}{l}\text { Graduated high } \\
\text { school type } \\
\text { Vocational School } \\
\text { Others } \\
\text { p }\end{array}$ & $\begin{array}{r}93(17.6) \\
435(82.4)\end{array}$ & $\begin{array}{r}73.6 \pm 13.43 \\
73.6 \pm 13.96 \\
0.996\end{array}$ & $\begin{array}{r}126.1 \pm 14.18 \\
125.4 \pm 14.43 \\
0.715\end{array}$ \\
\hline
\end{tabular}




\begin{tabular}{|c|c|c|c|}
\hline $\begin{array}{l}\text { Family' living } \\
\text { place } \\
\text { City } \\
\text { Other (district, } \\
\text { village, town) } \\
\text { p }\end{array}$ & $\begin{array}{l}232(43.9) \\
296(56.1)\end{array}$ & $\begin{array}{r}74.6 \pm 14.20 \\
72.7 \pm 13.55 \\
0.134\end{array}$ & $\begin{array}{r}127.1 \pm 14.77 \\
124.4 \pm 13.97 \\
0.032 *\end{array}$ \\
\hline $\begin{array}{l}\text { Family type } \\
\text { Nuclear Family } \\
\text { Extended family } \\
\text { Single Parent Family } \\
\text { p }\end{array}$ & $\begin{array}{rr}427 & (80.9) \\
79 & (15) \\
22 & (4.1)\end{array}$ & $\begin{array}{r}74.1 \pm 14.17 \\
70.2 \pm 12.95 \\
75.8 \pm 9.10 \\
0.059\end{array}$ & $\begin{array}{r}125.0 \pm 14.2 \\
125.7 \pm 14.2 \\
126.5 \pm 17.6 \\
0.893\end{array}$ \\
\hline $\begin{array}{l}\text { Income level } \\
\text { Less than } \\
\text { expenditure } \\
\text { Equal to expenditure } \\
\text { More than } \\
\text { expenditure } \\
\text { p }\end{array}$ & $\begin{array}{r}70(13.1) \\
215(40.5) \\
245(46.4)\end{array}$ & $\begin{array}{r}73.8 \pm 13.19 \\
72.9 \pm 13.49 \\
73.2 \pm 14.61 \\
0.599\end{array}$ & $\begin{array}{r}125.8 \pm 15.12 \\
125.6 \pm 14.23 \\
125.2 \pm 13.49 \\
0.646\end{array}$ \\
\hline $\begin{array}{l}\text { Father Education } \\
\text { level } \\
<\text { High school } \\
\geq \text { High school } \\
\text { p }\end{array}$ & $\begin{array}{l}292(55.3) \\
236(44.7)\end{array}$ & $\begin{array}{r}73.6 \pm 13.72 \\
73.5 \pm 14.05 \\
0.974\end{array}$ & $\begin{array}{r}126.1 \pm 14.39 \\
125.0 \pm 14.37 \\
0.400\end{array}$ \\
\hline $\begin{array}{l}\text { Mother } \\
\text { Education level } \\
<\text { High school } \\
\geq \text { High school } \\
\mathrm{p}\end{array}$ & $\begin{array}{l}335(63.4) \\
193(36.6)\end{array}$ & $\begin{array}{r}73.4 \pm 13.42 \\
73.8 \pm 14.61 \\
0.777\end{array}$ & $\begin{array}{r}126.4 \pm 14.27 \\
124.1 \pm 14.49 \\
0.087\end{array}$ \\
\hline $\begin{array}{l}\text { Father occupation } \\
\text { Officer } \\
\text { Farmer } \\
\text { Retired } \\
\text { Tradesman } \\
\text { Worker } \\
\text { P } \\
\end{array}$ & $\begin{array}{l}139(26.3) \\
86(16.3) \\
106(20.1) \\
79(15) \\
118(22.3)\end{array}$ & $\begin{array}{r}72.3 \pm 15.15 \\
73.3 \pm 13.35 \\
75.9 \pm 12.48 \\
71.1 \pm 12.76 \\
74.9 \pm 14.26 \\
0.097 \\
\end{array}$ & $\begin{array}{r}126.0 \pm 13.63 \\
127.1 \pm 14.77 \\
127.0 \pm 15.37 \\
123.5 \pm 14.15 \\
123.8 \pm 14.09 \\
0.233 \\
\end{array}$ \\
\hline $\begin{array}{l}\text { Mather } \\
\text { occupation } \\
\text { Officer } \\
\text { Retired } \\
\text { Tradesman } \\
\text { Worker } \\
\text { Housewife } \\
\text { p }\end{array}$ & $\begin{array}{r}31(5.9) \\
34(6.4) \\
13(2.5) \\
23(4.4) \\
427(80.8)\end{array}$ & $\begin{array}{r}73.1 \pm 16.45 \\
74.2 \pm 12.34 \\
73.1 \pm 12.61 \\
70.5 \pm 15.57 \\
73.9 \pm 13.67 \\
0.114\end{array}$ & $\begin{array}{r}126.2 \pm 15.52 \\
125.6 \pm 14.29 \\
128.5 \pm 15.44 \\
123.7 \pm 14.98 \\
12.4 \pm 14.25 \\
0.841\end{array}$ \\
\hline $\begin{array}{l}\text { Departments } \\
\text { Nursing } \\
\text { Physical Therapy } \\
\text { and } \\
\text { Rehabilitation } \\
\text { Elderly Care } \\
\text { p }\end{array}$ & $\begin{array}{r}310(58.7) \\
172(32.6) \\
46 \quad(8.7)\end{array}$ & $\begin{array}{r}73.3 \pm 13.95 \\
74.5 \pm 13.39 \\
72.3 \pm 14.99 \\
0.502\end{array}$ & $\begin{array}{r}126.8 \pm 15.48 \\
124.4 \pm 12.76 \\
121.8 \pm 11.31 \\
0.040^{*}\end{array}$ \\
\hline
\end{tabular}




\begin{tabular}{|l|r|r|r|}
\hline Year in school & $154(29.2)$ & $73.2 \pm 14.34$ & $124.5 \pm 15.41$ \\
1. year & $134(25.4)$ & $74.0 \pm 13.98$ & $127.7 \pm 16.05$ \\
2. year & $122(23.1)$ & $74.3 \pm 13.095$ & $125.8 \pm 12.95$ \\
3.year & $118(22.3)$ & $72.7 \pm 13.95$ & $124.3 \pm 12.10$ \\
4.year & & 0.791 & 0.184 \\
p & $528(100)$ & $73.6 \pm 13.81$ & $1256 \pm 14.38$ \\
\hline Total & & & \\
\hline
\end{tabular}

This study examined the students' attitudes and level of self-esteem. We found that the KOAP mean attitude score was $125.6 \pm 14.38$. The score indicates a favorable and slightly positive attitude towards the elderly (KAOP score above 102). Also, the mean self-esteem score was found as $73.6 \pm 13.81$ and it can be suggested that the student' levels of self-esteem were high. The students' SEI scores were compared with personal characteristics such as age, gender, but the difference was not found to be statistically significant $(p>0.05)$ The effects of personal characteristics on students' attitudes towards elders and students' self-esteem are presented in Table 1.

Table 2: KOAP Total, Positive and negative item mean score of students based on classes

\begin{tabular}{|c|c|c|c|c|c|c|}
\hline VARIA & \multicolumn{6}{|c|}{ YEAR OF STUDY } \\
\hline $\begin{array}{l}\text { KOAP } \\
\text { Scores } \\
\text { Mean } \\
\text { 土SD }\end{array}$ & $\begin{array}{c}\text { 1.year } \\
(n: 154) \\
(29.2 \%)\end{array}$ & $\begin{array}{c}\text { 2.year } \\
(n: 134) \\
(25.4 \%)\end{array}$ & $\begin{array}{c}\text { 3.year } \\
(n: 122) \\
(23.1 \%)\end{array}$ & $\begin{array}{c}\text { 4.year* } \\
(n: 118) \\
(22.3 \%)\end{array}$ & $\mathbf{F}$ & $\mathbf{P}$ \\
\hline KOAP+ & $65.2 \pm 9.85$ & $67.9 \pm 9.43$ & $65.6 \pm 8.71$ & $64.2 \pm 10.51$ & .634 & .594 \\
\hline KOAP- & $59.3 \pm 11.33$ & $59.8 \pm 10.59$ & $60.2 \pm 9.43$ & $60.1 \pm 9.84$ & .680 & .172 \\
\hline $\begin{array}{l}\text { Total } \\
\text { KOAP }\end{array}$ & $124.5 \pm 15.41$ & $127.7 \pm 16.0$ & $125.8 \pm 12.93$ & $124.3 \pm 12.1$ & & .184 \\
\hline
\end{tabular}

* Second year students of Elderly Care Department were included in this group (because they are in final year)

Table 3: KOAP Positive and negative item mean score of students based on the departments.

\begin{tabular}{|l|r|l|l|r|r|}
\hline VARIABLES & \multicolumn{5}{|c|}{ DEPARTMENTS } \\
\hline $\begin{array}{l}\text { KOAP' } \\
\text { Scores } \\
\text { Mean } \\
\text { ISD }\end{array}$ & Nursing & $\begin{array}{l}\text { Physical Therapy } \\
\text { and } \\
\text { Rehabilitation }\end{array}$ & $\begin{array}{l}\text { Elderly } \\
\text { Care }\end{array}$ & F & P \\
\hline KOAP+ & $65.1 \pm 9.71$ & $65.2 \pm 8.45$ & $66.1 \pm 10.51$ & .343 & .710 \\
\hline KOAP- & $61.5 \pm 9.53$ & $59.1 \pm 9.72$ & $55.6 \pm 11.13$ & 2.377 & .095 \\
\hline $\begin{array}{l}\text { Total } \\
\text { KOAP }\end{array}$ & $126.7 \pm 15.48$ & $124.4 \pm 12.76$ & $121.8 \pm 11.31$ & 3.237 & $.040 *$ \\
\hline \multicolumn{7}{|c|}{$* \mathrm{p}<0.05$} & & & & \\
\hline
\end{tabular}


The KAOP mean attitude scores were compared with personal characteristics using independent samples t-tests for variables dichotomized and one-way ANOVO test. Two characteristics significantly affected the students' attitudes towards the elderly: age and living in the city. Students were divided into two age groups and analysis by age groups indicated that there was an effect of age for negative attitudes towards the elderly, with students under 20 years of age $(P<0.05)$. Also, it was found that the attitude scores of students who lived in cities were higher than the others $(P<0.05)$. In terms of gender, the study findings indicated that female students had more positive attitude scores towards the elderly compared with male students, but the difference between the scores was not statistically significant $(p>0.05)$. However, family type, income, parents' education and occupation, and graduated high school type of students did not noticeably affect student' attitudes towards the elderly (Table 1). In addition to the total mean scores, the negative (KAOP-) and positive (KAOP+) item means of KAOP were scored and summed separately for comparison with variables. When examined based on class level, results indicated that there were no significant differences for all KAOP variables (negative, positive and total mean scores), although KAOP mean score was the highest for second class (Table 2). According to departments, students of Elderly Care Department had the lowest mean and there was a significant difference between KAOP mean scores of students of Nursing Department and Elderly Care Department. Also, students of Elderly Care Department had the lowest negative item score but not at a statistically significant level. For the positive item scores, all the departments had similar scores (Table 3).

Furthermore, in the study, the correlation between the KAOP and SEI mean scores was examined and a weak positive correlation was found $(r=0.281$; $\mathrm{p}<0.01)$.

\section{Discussion}

In this study, the results have been compared with other studies evaluating attitudes of health care professionals and students towards the elderly through KOAP scale. The results of the study showed that overall students had slightly positive attitudes towards the elderly based on total mean KAOP score (125.6 \pm 14.38). Another study on attitudes of Turkish medical and nursing students found a score quite close to our result (Total Mean KAOP score: 126.9) (Ayoğlu et al., 2013). In parallel with our research, it was determined that health care professionals or students had slightly positive attitude towards the elderly in studies performed in countries such as Sweden (Soderhamn et al., 2001), Jordan (Hweidi and Al-Obeisat, 2006), The U.S. (Nochajski, et al, 2009), Taiwan (Wang et al., 2009), China (Yen et al., 2009), Italy (Matarese et al., 2013), and Malawi (Zverev, 2013). The similar attitude findings towards the elderly that were obtained from different cultures can be explained as one of the effects of economic, social and cultural changes such as nations becoming closer together and similarity of cultural life that occurred during globalization. 
Overall, researchers have suggested various factors that can affect attitudes towards older people such as age, gender, culture, education, personality traits, clinical experience and past experience with the elderly (Katz, 1990; Soderhamn et al., 2001; Stewart et al., 2005; Hweidi and Al-Obeisat, 2006; Lambrinou et al., 2009; Bleijenberg et al., 2012; Topaz and Doron, 2013). Our study indicated that students at the age of 20 or over and living in the city had more positive attitudes. In the literature, there are conflicting results. Some studies pointed out that older health care professionals and students had more positive attitudes (Soderhamn et al., 2001; Stewart et al., 2005; Hweidi and AlObeisat, 2006; Lambrinou et al., 2009; Leung et al., 2011). However, Ayoğlu et al., (2013) reported no significant correlation between age and attitudes towards older people. As a second factor affecting attitude, we found that students who were living in the city had more positive attitudes. Conversely, no differences in attitudes were reported between those living in towns/villages or in the city (Hweidi and Al-Obeisat, 2006; Ayoğlu et al., 2013). Additionally, our study showed that there wasn't a statistically significant difference between family characteristics and attitudes of the students $(p>0.05)$. Similar findings were observed in the studies by Soyuer et al. (2010) and Usta Yıldırım et al, (2011).

Education level (Gallagher et al., 2006; Lambrinou et al., 2009; Usta Yildirim et al., 2012; Topaz and Doron, 2013) and work experience (Soderhamn et al., 2001; Leung et al., 2011) influence knowledge on aging and attitudes towards the elderly. In order to determine attitude and knowledge, various scales (such as Palmore's fact on aging quiz - FAQ), and comparisons among departments or classes were utilized (Stewart et al., 2005; Ayoğlu et al., 2013). Lambrinou et al., (2009) determined that correlations were between total score of knowledge on aging (FAQ) and the scores of Kogan's attitude subscale. We compared students' attitudes based on both their departments and also their class levels. As a result, it was found out that there was no significant difference among class levels ( $p>0.05$ ), but second year students' total KAOP scores and $\mathrm{KAOP}+$ were higher than the other class levels (Table 2). This finding may be interpreted as an increase in knowledge and awareness in geriatrics for this class level, because nursing students formed the majority of the participants (58.7\%) are provided with theoretical geriatric content in the Medical Nursing course with clinical experience during the second class. Similarly, Wang et al., (2009) suggested that second year students who have more opportunities to interact with older people have more positive attitudes than senior students. However, previous studies observed that students have more positive attitudes when class level increases (Soderhamn et al., 2001; Bleijenberg et al., 2012; Hweidi and Al-Obeisat, 2006). Our study showed that students' attitudes were not affected by their class levels. This finding is supported by another study conducted in Turkey (Ayoğlu et al, 2014). The results may be assumed that training provided the students is not effective on students' attitudes towards the elderly and it can be seen an evidence for the problems regarding geriatric/gerontology education. Therefore, the training curriculum should be 
arranged to enhance positive attitude towards the elderly and the knowledge on aging.

In Turkey, Elderly Care Departments were recently established to resolve the shortage of health care professionals who provide care needs, improve the quality of life and contribute to the development of health standards of older people, and have analytical thinking skills. Our study is the first research evaluating the attitudes of students in the Elderly Care Department towards the elderly. However, the students of the Elderly Care Department were found to have lower KAOP total mean scores than students of the other departments ( $p$ <.05). This result can be associated with lack of knowledge on the elderly and aging or not choosing the department willingly. The previous study on students of Elderly Care Department supports our observation. The study reported that only $37.5 \%$ of the students preferred the department willingly, and $72.5 \%$ had stated that the education that was given in the first year was not enough for their work life. These findings were attributed to the fact that either the curriculum or the physical conditions of the university were not efficient yet (Saruhan et al., 2013). Also, Gallagher et al. (2006) suggested that health care assistants had higher negative attitudes towards older adults than nurses because of inadequate training.

To determine the attitudes towards the elderly based on departments, besides total mean KAOP scores, KAOP- and KAOP+ mean scores were compared and meaningful differences were not found $(p>0.05)$. Similarly, Uğurlu et al., (2011) suggested that there were no significant differences in KAOP- and KAOP+ scores between Departments of Nursing and Physiotherapy \& Rehabilitation. Zverev, (2013) didn't detect meaningful difference between the attitudes of nursing and medical students towards the elderly.

Self-esteem is personal factor associated with attitudes (Findler et al, 2007) and is crucial for developing a strong and therapeutic relationship with patients (Hamoud et al., 2011; Öhlen and Segesten, 1998). In this study, selfesteem means score was determined as 73.6 \pm 13.81 (Table 1 ) and level of selfesteem was not related to any personal and family characteristics $(p>0.05)$. Our finding was consistent with SEI scores obtained from studies on nursing, midwifery, and education faculty students (Karagözoğlu et al., 2008). Also, Karagözoğlu et al., (2008) found that there were no statistically significant differences between the students' SEI mean scores and the students' age, residence, parents' educational status, and parents' occupations.

In the study, differently from the other studies evaluating attitudes towards the elderly, we examined effects of self-esteem on attitudes towards the elderly and found a positive relationship, albeit weak. Chung et al., (2003) reported a positive relationship between attitudes of health professionals towards alcoholic patients and their self-esteem. Another study found that the nurse with higher professional self-esteem had more positive attitudes towards the patients who bring in internet information (Barnoy et al., 2008). As seen in our study and other studies, self-esteem level of health care professionals is one of the factors affecting their attitudes towards the patients. Therefore, students' 
levels of self- esteem should be evaluated, and training programs ought to be planned to improve self-esteem by the counseling services.

According to the findings of this study, it can be suggested that the students studying in health related departments are required to improve positive attitude towards the elderly. Education is the way to maintain and enhance students' attitudes, but Gerontological/Geriatric education for the students studying in health related departments is not sufficiently popular. In our country, the students are mostly provided geriatric education, which is on diseases of aging as a subtopic of other courses. On the other hand, the curriculum includes less gerontological content which involves the care of the old people and emphasizes the promotion of the highest possible quality of life. Therefore, the training programs should include more geriatric and gerontological contents as basic courses. In particular, in addition to theoretical courses, practices and projects should be planned to increase interaction with the elderly (in clinics, nursing home, home visits to elderly). In addition to them, for the post graduate period, it is essential to regard this area as a specific expertise one and hence certificate programs should be expanded for the health care professionals working with the elderly, and number of master and $\mathrm{PhD}$ programs should be increased.

Furthermore, old people are persons who should be respected and appreciated in traditional Turkish society. The large family system and life bound to traditions in the past has changed to individual life style. The old people in a changing social system have lost their status and authority in the traditional family. As a result, negative attitudes towards the elderly have increased. The students' attitudes are not independent of societal attitudes. Thus, all society' attitudes need to be improved positively. Giving gerontological content in the school curriculum for children or on media may be an alternative way to enhance awareness of society towards the discrimination against older people.

\section{Conclusion}

In conclusion, the study indicated that the students studying in health related departments had slightly positive attitudes and the students' attitudes were affected by various variables such as age, living in the city and especially level of self-esteem. The result implies that Gerontological and Geriatric education is significant for the students. Summary, we can make the following suggestions:

- Enhancement of gerontological and geriatric education in undergraduate, postgraduate and lifelong education.

- Increasing interaction with the elderly

- Awareness of society towards the discrimination against the old people 


\section{References}

Ayoğlu, F. N., Kulakçı, H., Ayyıldız, T. K., Aslan, G. K., \& Veren, F. (2013). Attitudes of Turkish Nursing and Medical Students Toward Elderly People. Journal of Transcultural Nursing, 25(3), 241-248.

Barnoy, S., Volfin-Pruss, D., Ehrenfeld, M., Kushnir, T. (2008). Factors affecting nurses' attitudes in Israel toward patients who present them with Internet medical Information. Nursing Outlook, 56(6), 314-321.

Bleijenberg, N., Jansen, M. J. M., Schuurmans, M. J. (2012). Dutch nursing students' knowledge and attitudes towards older people-A longitudinal cohort study. Journal of Nursing Education and Practice, 2(2), 1-8.

Chung, J. Y. M., Chan, J. T. S., Yeung, R. S. D., Wan, R. C. H., Ho, S. T. (2003). Nurses' attitude toward alcoholic patients in accident and emergency department in Hong Kong. Hong Kong College of Emergency Medicine, 10(2), 104-112.

Coopersmith, S. (1986). Self-esteem Inventories. Consulting Psychologists Press, California.

Dimitriadou- Panteka, A., Koukourikos, K., Pizirtzidou, E. (2014). The Concept of Self-Esteem in Nursing Education and its Impact on Professional Behavior. International Journal of Caring Sciences, 7(1), 6-11.

Doherty, M., Mitchell, E. A., \& O'Neill, S. (2011). Attitudes of healthcare workers towards older people in a rural population: A survey using the Kogan Scale. Retrieved from http://www.hindawi.com/journals/nrp/2011/352627/

Erdemir, F., Kav, S., Citak, E.A., Hanoglu, Z., Karahan, A. (2011). A Turkish version of Kogan's attitude toward older people (KAOP) scale: reliability and validity assessment. Archives of Gerontology and Geriatrics, 30, 14.

Findler, L., Vilchinsky, N., Werner, S. (2007). The Multidimensional Attitudes Scale toward persons with disabilities (MAS): Construction and validation. Rehabilitation Counseling Bulletin, 50, 166-176.

Gallagher, S., Bennett, K. M., Halford, J. C. (2006). A comparison of acute and long-term health-care personnel's attitudes towards older adults. International Journal of Nursing Practice, 12 (5), 273-279.

Goodson, P., Buhi, E. R, Dunsmore, S. C. (2006). Self-esteem and adolescent sexual behaviors, attitudes, and intentions: a systematic review. Journal of Adolescent Health, 38, 310-319.

Hamoud, S. A., El Dayem, S. A., Ossman, L. H. (2011). The Effect of an Assertiveness Training Program on Assertiveness Skills and Self-Esteem of Faculty Nursing Students. Journal of American Science, 7(12), 10851096.

Hweidi, I. M., Al-Obeisat, S. M. (2006). Jordanian nursing students' attitudes toward the elderly. Nurse Education Today, 26(1), 23-30.

İnceoğlu, M. (2010). Tutum Algı İletişim. Retrieved from http://www.beykent.edu.tr/WebProjects/Uploads/METIN\%20INCEOGLU _Tutum-algi-iletisim.pdf. 
Karagozoglu, Ş., Kahve, E., Koc, O., Adamisoglu, D. (2008). Self-esteem and assertiveness of final year Turkish university students. Nurse Education Today, 28, 641-649

Katz, R. S. (1990). Personality trait correlates of attitudes toward older people. International Journal of Aging and Human Development, 31(2), 147-59.

Kearney, N., Miller, M., Paul, J., Smith, K. (2000). Oncology healthcare professionals' attitudes toward elderly people. Annals of Oncology, 11, 599-601.

Kogan, N. (1961). Attitudes toward old people: the development of a scale and examination of correlates. Journal of Abnormal and Social Psychology, 62, 44-54.

Lambrinou, E., Sourtzi, P., Kalokerinou, A., Lemonidou, C. (2009). Attitudes and knowledge of the Greek nursing students towards older people. Nurse Education Today, 29(6), 617-622.

Lee, Y. (2009). Measures of student attitudes on aging. Educational Gerontology, 35(2), 121-134.

Leung, S., LoGiudice, D., Schwarz, J., Brand, C. (2011). Hospital doctors' attitudes towards older people. Internal Medicine Journal, 41, 308-314.

Matarese, M., Lommi, M., Pedone, C., Alvaro, R., \& De Marinis, M. G. (2013). Nursing student attitudes towards older people: validity and reliability of the Italian version of the Kogan Attitudes towards Older People scale. Journal of Advanced Nursing, 69(1), 175-184.

Nochajski, T. H., Waldrop, D. P., Davis, E. L., Fabiano, J. A., \& Goldberg, L. J. (2009). Factors that influence dental students' attitudes about older adults. Journal of Dental Education, 73(1), 95-104.

Öhlen, J., Segesten, K., (1998). The professional identity of the nurse: concept analysis and development. Journal of Advanced Nursing, 28 (4), 720727

Saruhan, G., Evci Kiraz, E. D., Ergin, F., Beşer, E., Başaloğlu, H. (2013). Adnan Menderes University Elder Care Technician Program: Students' Expectations for Trade Branch. Journal of Adnan Menderes University Medical Faculty, 14(2), 19-23.

Soderhamn, O., Lindencrona, C., Gustavsson, S.M.. (2001). Attitudes towards older adults among nursing students and registered nurses in Sweden. Nurse Education Today, 21, 225-229.

Soyuer, F., Unalan, D., Guleser, N., Elmali, F. (2010). The attitudes health vocational school students towards ageism and the relation of these attitudes with some demographical variables. Mersin Üniversitesi Saglık Bilimleri Dergisi, 3, 20-25.

Stewart, J. J., Giles, L., Paterson, J. E., \& Butler, S. J. (2005). Knowledge and attitudes towards older people: New Zealand students entering health professional degrees. Physical \& Occupational Therapy in Geriatrics, 23(4), 25-36.

Topaz, M., Doron, I. (2013). Nurses attitudes toward older patients in acute care in Israel. Online Journal of Issues in Nursing, 18(2). Retrieved from http://www.nursingworld.org/MainMenuCategories/ANAMarketplace/AN 
APeriodicals/OJIN/TableofContents/Vol-18-2013/No2-May-2013/ArticlesPrevious-Topics/Nurses-Attitudes-Toward-Older-Patients-in-Israel.html.

Turan, N., Tufan, B. 1987. Validity and reliability study for Coopersmith selfesteem inventory (in Turkish). In Proceedings of the 23rd national psychiatry and neurological sciences congress book, 816-817.

TUIK (Turkish Statistical Institute), (2013). Retrieved from http://www.tuik.gov.tr/PreHaberBultenleri.do?id=15844

Uğurlu, N., Karakaya, M. G., Çıtak Karakaya, I., Subaşı Baybuğa, M., Demir Uysal, D., Acer, N., Yakın, B., Kogan, N. (2011). Turkish version of Kogan's old people scale: a validity and reliability study. Turkish Journal of Geriatrics, 14 (2), 145-153.

Usta Yıldırım, Y., Demir, Y., Yonder, M., Yildiz, A. (2012). Nursing students' attitudes toward ageism in Turkey. Archives of Gerontology and Geriatrics, 54, 90-93.

Wang, C., Liao, W., Kao, M., Chen, Y. J., Lee, M. C., Lee, M. F., Yen, C. H. (2009). Taiwanese medical and nursing student interest levels in and attitudes towards geriatrics. Annals Academy of Medicine Singapore, 38(3), 230-236.

Yen, C. H., Liao, W. C., Chen, Y. R., Kao, M. C., Lee, M. C., Wang, C. C. (2009). A Chinese version of Kogan's attitude toward older people scale: reliability and validity assessment. International Journal of Nursing Studies, 46(1), 38-44.

Zverev, Y., (2013). Attitude toward older people among Malawian medical and nursing students. Educational Gerontology, 39, 57-66. 